\title{
Targeting CD22 for the Treatment of B-Cell Malignancies
}

\author{
Nikesh N Shah' \\ Lubomir Sokol ${ }^{2}$ \\ 'Department of Internal Medicine, \\ Morsani College of Medicine, University \\ of South Florida, Tampa, FL, USA; \\ ${ }^{2}$ Department of Malignant Hematology, \\ $H$. Lee Moffitt Cancer Center and \\ Research Institute, Tampa, FL, USA
}

\begin{abstract}
Immunotherapeutic agents play an increasingly important role in the treatment of B-cell malignancies. CD19 and CD20 are common targets for lymphoid malignancies, though patients who relapse have few therapeutic options remaining. CD22 is a cell surface sialoglycoprotein uniquely present on B-cells and regulates B-cell function and proliferation. Thus, it is an appealing therapeutic target for autoimmune disorders and B-cell malignancies. A variety of therapies targeting CD22 have been developed, including monoclonal antibodies, antibody-drug conjugates, radioimmunoconjugates, chimeric antigen receptor $\mathrm{T}$ cells, and bispecific antibodies. Here, we review the biology of CD22 and key therapies targeting CD22 in lymphoid malignancies.
\end{abstract}

Keywords: CD22, epratuzumab, inotuzumab ozogamicin, bispecific antibody, chimeric antigen receptor, lymphoma, acute lymphoblastic leukemia

\section{Introduction}

B-cell malignancies are the fourth leading subtype of cancer, with over 130,000 new estimated cases annually in the United States in $2016 .{ }^{1}$ Among the lymphoid malignancies there is a wide spectrum of diseases ranging from precursor B-cell acute lymphoblastic leukemia (B-ALL) to more mature B-cell neoplasms such as marginal zone lymphoma. There is also significant heterogeneity of disease acuity, from indolent non-Hodgkin lymphomas (NHLs) like chronic lymphocytic leukemia (CLL) and follicular lymphoma (FL), which may be observed for some time, to aggressive diffuse large B-cell lymphoma (DLBCL) and B-ALL, which require prompt therapy.

Though cytotoxic chemotherapy remains the mainstay of treatment for aggressive lymphomas, the addition of immunotherapy and targeted therapies (notably, anti-CD20 therapies such as rituximab and obinutuzumab) have significantly improved outcomes. ${ }^{2,3}$ Anti-CD19 therapies including chimeric antigen receptor T-cells (CAR-T) and the bispecific antibody, blinatumomab (anti CD3 and CD19), have shown recent promise in lymphoid malignancies as well. Unfortunately, for patients who relapse or progress after anti-CD19 or anti-CD20 therapy there are limited therapeutic options.

CD22 presents an attractive target in lymphoid neoplasms given its unique presence in B-lymphocytes. Due to its role in regulating B-cell function, CD22 has also been targeted in autoimmune diseases such as systemic lupus erythematosus and Sjogren syndrome. In this review, we will focus on the biology of CD22 and the therapeutic implications in lymphoid malignancies.
Correspondence: Lubomir Sokol Department of Malignant Hematology, $\mathrm{H}$. Lee Moffitt Cancer Center and Research Institute, 12902 USF Magnolia Drive, Tampa, FL, 336I2, USA

Email lubomir.sokol@moffitt.org 


\section{CD22 Biology}

$\mathrm{CD} 22$ is a $135 \mathrm{kDa}$ cell surface transmembrane sialoglycoprotein and is classified under the immunoglobulin superfamily. It consists of seven extracellular immunoglobulin domains and a 141-amino acid cytoplasmic tail. CD22 is uniquely expressed in B-lymphocytes, and it is expressed in higher concentrations on mature B-lymphocytes than precursor B-cells. ${ }^{4}$ In particular, it is strongly expressed in marginal zone, mantle, and follicular B-cells.

Functionally, CD22 has been implicated in regulating B-cell survival and function. It is involved in B-cell intercellular adhesion and binds to $\alpha 2-6$-linked sialic acid residues of glycoproteins on other leukocytes, erythrocytes, and endothelial cells. ${ }^{4} \mathrm{CD} 22$ also regulates B-cell receptor (BCR) signaling. In vitro studies have shown that CD22 can generate stimulatory signals promoting cell proliferation; conversely, $\mathrm{CD} 22$ can also promote apoptotic signals via the $\mathrm{BCR}$, leading to B-cell death. ${ }^{5,6} \mathrm{CD} 22$-knockout mice have shorter survival and decreased circulating B-cells. ${ }^{4}$ Over the past 15 years, several different classes of immunotherapeutic agents have been tested in patients with B-cell malignancies in clinical trials (Figure 1).

\section{Anti-CD22 Therapeutics Naked Antibodies}

Epratuzumab is a humanized IgG antibody against CD22, derived from the murine IgG2 monoclonal antibody, LL2. It phosphorylates CD22, affects BCR signaling by Ig crosslinking, and induces antibody-directed cellular cytotoxicity. ${ }^{4}$ Epratuzumab has been investigated in combination with chemotherapy or rituximab in both NHLs and B-ALL.

Epratuzumab has been studied in early phase trials in adults and children with relapsed/refractory B-ALL and showed potential anti-leukemia activity. The Children's Oncology Group (COG) led Phase I and II trials evaluating epratuzumab in combination with re-induction chemotherapy in children with B-ALL. ${ }^{7,8}$ In the Phase II trial, 114 children with relapsed B-ALL received re-induction chemotherapy as per COG AALL01P2 (vincristine, prednisone, pegasparaginase, doxorubicin, cyclophosphamide, etoposide, methotrexate, cytarabine, L-asparaginase) plus epratuzumab added weekly for four weeks or twice weekly for four weeks during the first re-induction cycle. ${ }^{9}$ The addition of epratuzumab was well-tolerated, with no unexpected adverse events attributed to epratuzumab. The complete response (CR) rate was $66 \%$, similar to historical cohorts. The rate of minimal residual disease (MRD)-negativity was up to $39 \%$, which was a non-significant trend towards improvement compared with historical numbers. SWOG S0910 assessed the activity and safety of adding epratuzumab to clofarabine and cytarabine for 35 adults with relapsed/refractory B-ALL. ${ }^{10}$ Compared with a prior SWOG study of clofarabine and cytarabine, the addition of epratuzumab showed an improved CR rate of $52 \%$ (compared with $17 \%$ for clofarabine/cytarabine alone), with one patient achieving MRD-negativity. ${ }^{11}$ Median overall
A

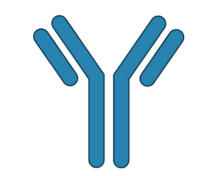

$\mathbf{E}$

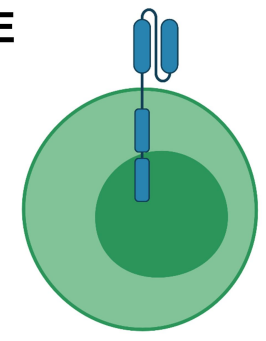

B

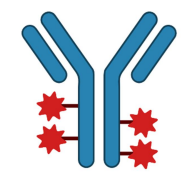

C

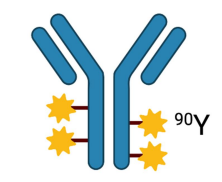

D

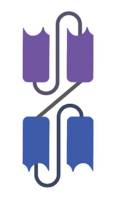

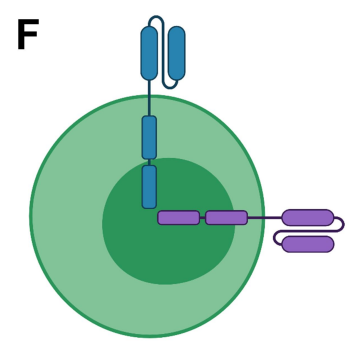

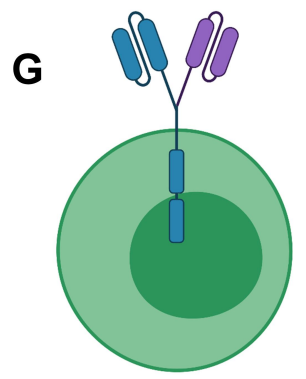

Figure I Legend: Simplified schema depicting current therapies targeting CD22 in B-cell malignancies. (A) Naked antibody; (B) Antibody-drug conjugate; (C) Radioimmunoconjugate; (D) Bispecific antibody/bispecific T-cell engager; (E) Chimeric antigen receptor (CAR)-T cell; (F) Bispecific CAR-T cell; (G) Tandem bispecific CAR-T cell. Abbreviations: ${ }^{90} \mathrm{Y}$, Yttrium-90. Figure created with BioRender.com. 
survival (OS) was 5 months. Three patients died during treatment, one with pneumonia and two attributed to cardiac arrest. Another phase II trial evaluated the use of weekly epratuzumab in combination with vincristine and dexamethasone in 25 older patients with relapsed/refractory CD22+ B-ALL. ${ }^{12}$ The overall response rate (ORR) was $40 \%$, with $20 \%$ achieving CR and 20\% achieving partial response (PR). Two patients were MRD-negative. Median OS was 4 months, and no patients went on to receive allogeneic stem cell transplant (alloSCT) due to early relapse. Pancytopenia was the most common grade 3-4 toxicity.

Epratuzumab has also been investigated in patients with NHLs, including DLBCL, FL, and small lymphocytic leukemia (SLL). Multiple early phase studies demonstrated a reasonable safety profile with addition of epratuzumab to rituximab for patients with relapsed/refractory NHL. ${ }^{13-16}$ A phase II trial evaluated this dual antibody combination in 49 patients with indolent NHL (49 with FL, 7 with SLL). ${ }^{17}$ Patients received epratuzumab plus rituximab weekly for 4 weeks. Fifty-four percent of patients with FL had an objective response (OR), 24\% had CR, and median PFS was 10 months. Among FL patients achieving $\mathrm{CR}$, median duration of response (DoR) was 29 months with some patients in CR over 4 years. Fifty-seven percent of the patients with SLL demonstrated an OR, 43\% had CR, and median PFS was 20 months. Among SLL patients achieving CR, median duration of response (DoR) was 20 months. Epratuzumab and rituximab were well tolerated, with no patients discontinuing due to toxicity.

In an effort to improve frontline therapy in DLBCL, a phase II study evaluated the addition of epratuzumab to frontline rituximab, cyclophosphamide, doxorubicin, vincristine, prednisone (RCHOP) in 107 patients with treatment naïve DLBCL. ${ }^{18,19}$ Epratuzumab was given on day 1 with each cycle. RCHOP with epratuzumab was welltolerated, with toxicities as expected with RCHOP, notably, myelosuppression. Eighty-nine percent of patients completed all 6 cycles. The ORR was 96\%, with $75 \%$ CR and 22\% PR. Three-year OS was 80\%, 3-year progression-free survival (PFS) was $76 \%$, both trending towards improvement compared with historical cohorts.

At present, epratuzumab is not FDA-approved or recommended by the national comprehensive cancer network (NCCN) guidelines for use in B-ALL or NHLs, potentially due to limited efficacy, short duration of response in some patients, and alternative treatment agents as discussed below. The most significant toxicities of epratuzumab include infusion reaction, myelosuppression, and febrile neutropenia, though the two latter may be attributed to other drugs given in combination.

\section{Antibody-Drug Conjugates}

Multiple antibody-drug conjugates (ADCs) have been developed using the CD22 epitope for targeted delivery of toxic payloads to B-cell lymphoma/leukemia cells. Most notable in this class is inotuzumab ozogamicin, an ADC comprised of a human anti-CD22 antibody attached to calicheamicin, a DNA-damaging agent that leads to apoptosis when intracellularly activated. $^{20}$ The INOVATE trial randomized 326 adults with relapsed/refractory B-ALL to inotuzumab ozogamicin monotherapy vs standard of care (SoC) intensive chemotherapy (eg, FLAG, high-dose cytarabine). ${ }^{21,22}$ At final analysis, inotuzumab ozogamicin had superior OS and PFS than SoC chemotherapy. Median PFS was 5 months and median OS was 7.7 among patients receiving inotuzumab ozogamicin, while median PFS was 1.7 months and median OS was 6.2 months among patients receiving SoC. Patients receiving inotuzumab ozogamicin had higher CR rates (74\% vs $35 \%$ ), higher rates of MRD-negativity (78\% vs $28 \%$ ), and more patients receiving inotuzumab ozogamicin underwent subsequent alloSCT. Veno-occlusive disease (VOD) occurred in $14 \%$ of patients receiving inotuzumab ozogamicin, with 5 patients dying from VOD after alloSCT and one patient dying from multiorgan failure (with grade 4 VOD). VOD is of particular concern since many B-ALL patients will be considered for alloSCT in $\mathrm{CR}$, and pre-transplant myeloablative conditioning regimens increase risk of VOD as well. The FDA approved inotuzumab ozogamicin for patients with relapsed or refractory Philadelphia chromosome-negative or Philadelphia chromosome-positive ALL based on data from the INO-VATE ALL study in 2017.

Inotuzumab ozogamicin has been combined with lower-intensity chemotherapy and blinatumomab in 48 patients with B-ALL in first relapse. ${ }^{23}$ The lowerintensity chemotherapy, termed mini-CVD, included lower dose cyclophosphamide, dexamethasone, vincristine, and methotrexate. The majority (92\%) of patients had an OR, with $73 \%$ achieving $\mathrm{CR}$ and $93 \%$ of those with CR achieving MRD-negativity. Fifty percent of patients proceeded to alloSCT in CR2. Median PFS was 11 months, and median OS was 25 months. Ten percent of patients developed VOD. In the trial, propensity score matching with historical cohorts showed improved 
outcomes with the combination of mini-CVD with inotuzumab ozogamicin and blinatumomab versus inotuzumab ozogamicin monotherapy or intensive salvage chemotherapy.

Inotuzumab ozogamicin has been evaluated in the front-line setting combined with mini-CVD in older patients with newly diagnosed Philadelphia chromosome negative (Ph-) B-ALL, as these patients may be unable to undergo the rigor of intensive induction chemotherapy due to age, frailty, or comorbidities. ${ }^{24}$ Fifty-two patients were enrolled to receive mini-CVD and inotuzumab ozogamicin. Two-year PFS was 59\%. This PFS appears slightly lower than the 2-year PFS near 75\% reported by Martell et al, in elderly patients who received the modified Dana Farber Cancer Institute protocol, though cross-trial comparisons must be interpreted with caution. ${ }^{25}$ Mini-CVD plus inotuzumab ozogamicin was relatively welltolerated, though $8 \%$ of patients developed VOD. Six patients $(12 \%)$ died from treatment-related causes, five from sepsis and one from VOD. Inotuzumab ozogamicin plus mini-CVD remains an effective treatment option for elderly Ph- B-ALL patients with a manageable safety profile compared with intensive induction chemotherapy.

Multiple trials have evaluated inotuzumab ozogamicin in NHLs with less promising results than those seen among patients with B-ALL. ${ }^{26-28}$ A Phase III trial randomized 338 patients with relapsed/refractory aggressive NHL to receive rituximab plus investigator's choice of chemotherapy (ie, bendamustine or gemcitabine) vs rituximab plus inotuzumab ozogamicin. ${ }^{29}$ The trial was terminated for futility in the first interim analysis per pre-established criteria for OS. Final analysis of available data showed similar median OS in both groups of 9.5 months.

Moxetumomab pasudotox-tdfk is another ADC targeting CD22, and it is FDA approved for use in patients with relapsed or refractory hairy cell leukemia (HCL) after two lines of prior therapy. It is a recombinant immunotoxin consisting of a fragment variable (Fv) of murine antiCD22 monoclonal antibody fused to a truncated $38 \mathrm{kDa}$ portion of Pseudomonas exotoxin A. ${ }^{30}$ In the pivotal trial, 80 patients with relapsed/refractory HCL after two or more lines of prior therapy received moxetumomab pasudotox for up to 6 cycles. $^{31} \mathrm{CR}$ rate was $41 \%$, durable $\mathrm{CR}$ rate was $30 \%$, and ORR was $75 \%$. 80\% achieved hematologic remission. Severe toxicities included hemolytic uremic syndrome (HUS) in 7.5\% and capillary leak syndrome (CLS) in 5\% of patients; both toxicities were reversible. Moxetumomab pasudotox has also been studied in pediatric and adult relapsed/refractory B-ALL patients with less promising results. ${ }^{32,33}$ The phase II trial in children was terminated at interim analysis due to low $\mathrm{CR}$ rate of $10 \% .^{32}$ In adults, toxicities included grade 3 HUS in one patient and grade $4 \mathrm{CLS}$ in one patient. ${ }^{33}$ Of note, moxetumomab pasudotox is an improved form of a previously studied anti-CD22 ADC joined with the Pseudomonas exotoxin, known as BL22. ${ }^{30}$ Moxetumomab pasudotox was found to be more active in pre-clinical models and in early phase trials as well. $^{30,34-36}$

Two other anti-CD22 ADCs have been clinically evaluated but not currently FDA approved. The immunotoxin IgG-RFB4-SMPT-dgA has a deglycosylated ricin A chain joined to a CD22 antibody. ${ }^{37}$ In an early-phase dosefinding study with 18 patients with B-cell lymphomas, 4 patients had best response of PR, no patients had a CR. Eleven of 18 patients developed CLS, with 7 patients experiencing grade 3-5 CLS. DT2219 is a bispecific ligand-directed toxin incorporating single-chain variable fragments targeting CD19 and CD22 fused to a portion of the diphtheria toxin. ${ }^{38}$ A study with 18 patients with NHL showed only 3 patients with, "objective clinical benefit," and one patient developed grade 4 CLS.

\section{Radioimmunoconjugates}

Two radioimmunoconjugates targeting CD22 have been developed: epratuzumab tetraxetan and BAY1862864. ${ }^{90} \mathrm{Y}$-epratuzumab tetraxetan is comprised of epratuzumab (anti-CD22 antibody as previously described) conjugated with a 1,4,7,10-tetraazacyclododecane-N,N',N",N"'tetraacetic acid chelator and labeled with 90-yttrium $\left({ }^{90} \mathrm{Y}\right)$, allowing for targeted delivery of the radioisotope to B-cells and causing cell death via beta decay. ${ }^{39}$ Epratuzumab tetraxetan was studied in 64 patients with relapsed/refractory NHL with an ORR of $62 \%$, CR rate of $48 \%$, and median PFS of 9.5 months. ${ }^{40}$ Two patients had grade 4 cytopenias attributed to the radioisotope. Epratuzumab tetraxetan was also evaluated in combination with the anti-CD20 antibody veltuzumab in 18 patients with relapsed/refractory aggressive NHL. ${ }^{41}$ ORR was $53 \%$, CR rate was $18 \%$, and $\mathrm{PR}$ rate was $35 \%$. Thirteen patients had grade 3-4 neutropenia or thrombocytopenia. More recently, epratuzumab tetraxetan was evaluated as consolidation following RCHOP in 71 elderly transplantineligible patients with DLBCL. ${ }^{42}$ Eighty-three percent of enrolled patients received epratuzumab tetraxetan. The ADC improved $\mathrm{PR}$ to $\mathrm{CR}$ in 8 patients for a total $68 \%$ 
CR rate. 2-year OS was $83 \%$. Toxicity included $84 \%$ of patients with grade 3-4 thrombocytopenia, 79\% with grade 3-4 neutropenia, and two patients with secondary myeloid neoplasms (one patient developed myelodysplastic syndrome 2 years after therapy, and one patient developed acute myeloid leukemia 5 months after therapy). This trial warrants comparison with ${ }^{90} \mathrm{Y}$ ibritumomab tiuxetan, a radioimmunoconjugate targeting $\mathrm{CD} 20$ that was similarly used in consolidation after CHOP among elderly patients with DLBCL. ${ }^{43}$ Ibritumomab tiuxetan appears to have higher efficacy, with CR rate of $100 \%$ and 2-year OS 95\%. Though not FDA approved for use in DLBCL, ibritumomab tiuxetan is approved for use in low-grade NHL or FL as consolidation or in the relapsed/refractory setting.

BAY1862864 is an anti-CD22 antibody radiolabeled with 227-thorium. 227-thorium causes cell death and cell cycle arrest via DNA damage from alpha particle emission, also known as alpha particle therapy. ${ }^{44}$ The first-inhuman study evaluated its use in 21 patients with NHL. The ORR was $38 \%$, with $19 \%$ of patients achieving PR and 5\% achieving CR. Toxicities included myelosuppression. The follow-up period was terminated early due to patients with progression enrolling into other clinical trials.

\section{CAR-T Therapies}

Anti-CD19 CARs have shown significant promise and are now FDA-approved for use in relapsed/refractory DLBCL, FL, and mantle cell lymphoma. Unfortunately, some patients relapse after CD19 CAR therapy, with few options available. B-ALL has seen less success with anti-CD19 CAR therapy than NHLs. CD22 is an appealing target for CARs and has shown promising efficacy and safety results in early phase trials, especially in B-ALL patients. A novel anti-CD22 CAR with 41BB and $\mathrm{CD} 3 \zeta$ costimulatory domains was developed and tested for safety in 21 pediatric and young adult patients with relapsed/refractory B-ALL, with $80 \%$ previously receiving CD19 targeted therapy. ${ }^{45}$ Grade 1-2 cytokine release syndrome (CRS) occurred in $76 \%$ of patients. In a subsequent study, the same group incorporated CD4/CD8 selection of the apheresis product to improve the CAR manufacturing process. ${ }^{46}$ Fifty-eight pediatric and young adult patients with relapsed/refractory B-ALL were treated with CD22-CAR after CD4/CD8 selection. Eighty-eight percent of patients had prior CD19 therapy and 67\% had prior alloSCT. Seventy percent of patients achieved CR, with $88 \%$ of those having MRD-negativity. The median OS was 13.4 months and leukemia-free survival was 6 months. The longest CR was over 3.5 years. Interestingly, response rates were not affected by receipt of prior CD19 therapy or alloSCT. The majority of patients who relapsed had CD22-negative or -dim disease at relapse, suggesting antigen escape as one possible mechanism for relapse. Eightysix percent of patients had CRS, majority (90\%) grade 12 , with median onset 7 days and median duration of 5 days. Two patients had grade 5 toxicity: one with sepsis and multiorgan dysfunction and another with CLS during CRS leading to grade 5 acute respiratory distress syndrome. Thirty-three percent of patients had neurotoxicity, all but one with grade $1-2$; the exception was a patient with grade 4 intracranial hemorrhage potentially attributed to Bacillus cereus bacteremia. Hemophagocytic lymphohistiocytosis/macrophage activation syndrome (HLH/ MAS) occurred in 5/7 patients at dose-level 2 and only in the setting of CRS. Thirty-eight percent of patients with CRS developed HLH/MAS-type symptoms, with median onset 14 days. CD4/CD8 selection was associated with increased rates of HLH/MAS. Fourteen patients required HLH-directed therapy with anakinra and/or corticosteroids, and HLH/MAS resolved in all patients. CD22directed CARs show promising efficacy in this relapsed/ refractory disease with limited therapeutic options and may provide a bridge to alloSCT.

There are many ongoing trials evaluating novel CD22directed CARs. Bispecific CD20/CD22 CARs and CD19/ CD22 CARs are in development, in an attempt to prevent relapse by minimizing antigen escape. A proof-of-concept study with a CD19/CD22 CAR in relapsed/refractory B-ALL enrolled 6 patients, with 100\% achieving CR with MRD-negativity. No neurotoxicity was observed. ${ }^{47}$ Other CARs under investigation include anti-CD22 CAR natural killer (NK) cells, anti-CD19/CD22 bispecific CAR NK cells, anti-programmed cell death ligand-1 "armored" CD22 CAR $T$ cells and CAR tumor infiltrating lymphocytes. $^{48}$ There is also a trispecific CD19/CD20/ CD22 CAR-T cell in preclinical development. ${ }^{49}$

\section{Bispecific Antibodies}

In addition to CAR-T cells, bispecific antibodies and bispecific T-cell engagers have also shown significant promise in lymphoid malignancies via a different mechanism for T-cell engagement. Blinatumomab is an FDA-approved bispecific T-cell engager targeting CD19 and CD3, which is present on T-cells, activating the host's endogenous 
Table I Selected Ongoing Studies Investigating CD22 Targeted Therapies in B-Cell Malignancies

\begin{tabular}{|c|c|c|c|}
\hline Title & $\begin{array}{l}\text { Trial } \\
\text { Number }\end{array}$ & Status & Phases \\
\hline $\begin{array}{l}\text { SI3I2, Inotuzumab Ozogamicin and Combination Chemotherapy in Treating Patients With } \\
\text { Relapsed or Refractory Acute Leukemia }\end{array}$ & NCT01925I3। & $\begin{array}{l}\text { Active, not } \\
\text { recruiting }\end{array}$ & Phase I \\
\hline Inotuzumab Ozogamicin for Children With MRD Positive CD22+ Lymphoblastic Leukemia & NCT039I3559 & Recruiting & Phase 2 \\
\hline $\begin{array}{l}\text { Study of Inotuzumab Ozogamicin Combined to Chemotherapy in Older Patients With } \\
\text { Philadelphia Chromosome-negative CD22+ B-cell Precursor ALL }\end{array}$ & NCT03249870 & Recruiting & Phase 2 \\
\hline Study of Anti-CD22 CAR-T Cells Treating Leukemia Children & NCT04340I67 & Recruiting & Phase 2 \\
\hline Study of Sequential CAR-T Cell Treating Leukemia Children & NCT04340I54 & Recruiting & Phase 2 \\
\hline $\begin{array}{l}\text { Inotuzumab Ozogamicin and Chemotherapy in Treating Patients With Leukemia or Lymphoma } \\
\text { Undergoing Stem Cell Transplantation }\end{array}$ & NCT03856216 & Recruiting & Phase 2 \\
\hline $\begin{array}{l}\text { Inotuzumab Ozogamicin in Treating Patients With B-cell Acute Lymphocytic Leukemia With } \\
\text { Positive Minimal Residual Disease }\end{array}$ & NCT0344I06I & Recruiting & Phase 2 \\
\hline $\begin{array}{l}\text { Targeting CDI9 and CD22 CAR-T Cells Immunotherapy in Patients With Relapsed or } \\
\text { Refractory Acute B Lymphocytic Leukemia }\end{array}$ & NCT047I4593 & Recruiting & $\begin{array}{l}\text { Phase II } \\
\text { Phase } 2\end{array}$ \\
\hline $\begin{array}{l}\text { CD19/CD22 Chimeric Antigen Receptor (CAR) T Cells in Children and Young Adults With } \\
\text { Recurrent or Refractory CD19/CD22-expressing B Cell Malignancies }\end{array}$ & NCT03448393 & Recruiting & Phase I \\
\hline Adult B-ALL Treated by CART Cell Bridging Allogeneic Hematopoietic Stem Cell Transplantation & NCT04626726 & Recruiting & $\begin{array}{l}\text { Early } \\
\text { Phase I }\end{array}$ \\
\hline $\begin{array}{l}\text { Inotuzumab Ozogamicin and Vincristine Sulfate Liposome in Treating Patients With Relapsed or } \\
\text { Refractory CD22+ B-cell Acute Lymphoblastic Leukemia }\end{array}$ & NCT0385I08I & Recruiting & $\begin{array}{l}\text { Phase II } \\
\text { Phase } 2\end{array}$ \\
\hline $\begin{array}{l}\text { Inotuzumab Ozogamicin and Frontline Chemotherapy in Treating Young Adults With Newly } \\
\text { Diagnosed B Acute Lymphoblastic Leukemia }\end{array}$ & NCT03I50693 & Recruiting & Phase 3 \\
\hline $\begin{array}{l}\text { Inotuzumab Ozogamicin and Combination Chemotherapy in Treating Older Patients With } \\
\text { Previously Untreated Acute Lymphoblastic Leukemia }\end{array}$ & NCT01371630 & Recruiting & $\begin{array}{l}\text { Phase II } \\
\text { Phase } 2\end{array}$ \\
\hline $\begin{array}{l}\text { Phase I/II Study of Bosutinib in Combination With Inotuzumab Ozogamicin in CD22-positive PC } \\
\text { Positive ALL and CML }\end{array}$ & NCT023II998 & Recruiting & $\begin{array}{l}\text { Phase II } \\
\text { Phase } 2\end{array}$ \\
\hline $\begin{array}{l}\text { Inotuzumab Ozogamicin and Blinatumomab in Treating Patients With Newly Diagnosed, } \\
\text { Recurrent, or Refractory CD22-Positive B-Lineage Acute Lymphoblastic Leukemia }\end{array}$ & NCT037398I4 & Recruiting & Phase 2 \\
\hline $\begin{array}{l}\text { Blinatumomab, Inotuzumab Ozogamicin, and Combination Chemotherapy as Frontline Therapy } \\
\text { in Treating Patients With B Acute Lymphoblastic Leukemia }\end{array}$ & NCT02877303 & Recruiting & Phase 2 \\
\hline $\begin{array}{l}\text { CD19/CD22 Chimeric Antigen Receptor(CAR) T Cells in Adults With Recurrent/Refractory } \\
\text { B Cell Malignancies }\end{array}$ & NCT03233854 & Recruiting & Phase I \\
\hline $\begin{array}{l}\text { Phase I Dose Escalation Study of CDI9/CD22 Chimeric Antigen Receptor (CAR) T Cells in } \\
\text { Children and Young Adults With Recurrent or Refractory B Cell Malignancies }\end{array}$ & NCT03241940 & Recruiting & Phase I \\
\hline $\begin{array}{l}\text { A Feasibility and Safety Study of Universal Dual Specificity CDI9 and CD20 or CD22 CAR-T Cell } \\
\text { Immunotherapy for Relapsed or Refractory Leukemia and Lymphoma }\end{array}$ & NCT03398967 & Recruiting & $\begin{array}{l}\text { Phase II } \\
\text { Phase } 2\end{array}$ \\
\hline CD22 Redirected Autologous T Cells for ALL & NCT026504I4 & Recruiting & Phase I \\
\hline $\begin{array}{l}\text { A Clinical Research of CDI9 and CD22 Targeted Prime CAR-T Cell in Relapsed/Refractory } \\
\text { B Cell Lymphoma }\end{array}$ & NCT04782193 & $\begin{array}{l}\text { Active, not } \\
\text { recruiting }\end{array}$ & $\begin{array}{l}\text { Phase II } \\
\text { Phase } 2\end{array}$ \\
\hline
\end{tabular}

(Continued) 
Table I (Continued).

\begin{tabular}{|c|c|c|c|}
\hline Title & $\begin{array}{l}\text { Trial } \\
\text { Number }\end{array}$ & Status & Phases \\
\hline Multi-CAR-T Cells Targeting B Cell Lymphomas & NCT04429438 & Recruiting & $\begin{array}{l}\text { Phase II } \\
\text { Phase } 2\end{array}$ \\
\hline $\begin{array}{l}\text { Anti-CD22 Chimeric Antigen Receptor (CAR)-Modified T Cell Therapy for Relapsed Refractory } \\
\text { B-cell Malignancies }\end{array}$ & NCT04007978 & Recruiting & Phase I \\
\hline CD22-CAR T Cells in Children and Young Adults With B Cell Malignancies & NCT04088864 & Recruiting & Phase I \\
\hline Safety and Efficacy of ThisCART22 in Patients With Refractory or Relapsed B Cell Malignancies & NCT0460II8I & Recruiting & Phase I \\
\hline $\begin{array}{l}\text { Safety and Efficacy Study of CD22 CAR-T Cells for Relapsed or Refractory Acute Lymphoblastic } \\
\text { Leukemia }\end{array}$ & NCT04546906 & Recruiting & $\begin{array}{l}\text { Not } \\
\text { Applicable }\end{array}$ \\
\hline $\begin{array}{l}\text { A Clinical Research of CDI9 and CD22 Targeted Prime CAR-T Cell in Relapsed/Refractory } \\
\text { B-ALL }\end{array}$ & NCT0478I634 & $\begin{array}{l}\text { Active, not } \\
\text { recruiting }\end{array}$ & $\begin{array}{l}\text { Phase II } \\
\text { Phase } 2\end{array}$ \\
\hline Bispecific CDI9/CD22 CAR-T for Treatment of Children and Young Adults With r/r B-ALL & NCT04499573 & Recruiting & $\begin{array}{l}\text { Phase II } \\
\text { Phase } 2\end{array}$ \\
\hline Autologous CD22 CAR T Cells in Adults w/ Recurrent or Refractory B Cell Malignancies & NCT04088890 & Recruiting & Phase I \\
\hline $\begin{array}{l}\text { Phase I Study of UCART22 in Patients With Relapsed or Refractory CD22+ B-cell Acute } \\
\text { Lymphoblastic Leukemia (BALLI-0I) }\end{array}$ & NCT04I50497 & Recruiting & Phase I \\
\hline A Study of GC022F CAR-T Cell Immunotherapy for Relapsed or Refractory B- ALL & NCT04I 29099 & Recruiting & $\begin{array}{l}\text { Early } \\
\text { Phase I }\end{array}$ \\
\hline Sequential CDI9 and CD22 CAR-T Therapy for Newly Diagnosed Ph+ B-ALL & NCT04788472 & Recruiting & $\begin{array}{l}\text { Phase II } \\
\text { Phase } 2\end{array}$ \\
\hline Sequential CDI9 and CD22 CAR-T Therapy for Newly Diagnosed Ph- B-ALL & NCT04740203 & Recruiting & $\begin{array}{l}\text { Phase II } \\
\text { Phase } 2\end{array}$ \\
\hline CAR-T Immunotherapy Targeting CDI9- ALL & NCT04016129 & Recruiting & $\begin{array}{l}\text { Phase II } \\
\text { Phase } 2\end{array}$ \\
\hline CD19 and CD22 Dual-targeted CAR-T Cells for Relapsed or Refractory B-NHL & NCT04303247 & $\begin{array}{l}\text { Not yet } \\
\text { recruiting }\end{array}$ & $\begin{array}{l}\text { Early } \\
\text { Phase I }\end{array}$ \\
\hline Combination CAR-T Cell Therapy Targeting Hematological Malignancies & NCT03। 25577 & Recruiting & $\begin{array}{l}\text { Phase II } \\
\text { Phase } 2\end{array}$ \\
\hline A Study of GC022F CAR-T Cell Immunotherapy for Relapsed or Refractory B- NHL & NCT044I 2174 & $\begin{array}{l}\text { Not yet } \\
\text { recruiting }\end{array}$ & $\begin{array}{l}\text { Early } \\
\text { Phase I }\end{array}$ \\
\hline $\begin{array}{l}\text { ADCT-602 in Treating Patients With Recurrent or Refractory B-cell Acute Lymphoblastic } \\
\text { Leukemia }\end{array}$ & NCT03698552 & Recruiting & $\begin{array}{l}\text { Phase II } \\
\text { Phase } 2\end{array}$ \\
\hline 4SCAR-T Therapy Post CDI9-targeted Immunotherapy & NCT04430530 & Recruiting & $\begin{array}{l}\text { Phase II } \\
\text { Phase } 2\end{array}$ \\
\hline $\begin{array}{l}\text { Modified Immune Cells (CD19-CD22 CAR T Cells) in Treating Patients With Recurrent or } \\
\text { Refractory CD19 Positive, CD22 Positive Leukemia or Lymphoma }\end{array}$ & NCT04029038 & $\begin{array}{l}\text { Not yet } \\
\text { recruiting }\end{array}$ & $\begin{array}{l}\text { Phase II } \\
\text { Phase } 2\end{array}$ \\
\hline Anti-CD19/CD22 Bispecific CAR-T Cell Therapy for CD19-positive ALL & NCT04303520 & Recruiting & Phase I \\
\hline CART22 Alone or in Combination With huCARTI9 for ALL & NCT03620058 & $\begin{array}{l}\text { Active, not } \\
\text { recruiting }\end{array}$ & Phase I \\
\hline
\end{tabular}


Table I (Continued).

\begin{tabular}{|c|c|c|c|}
\hline Title & $\begin{array}{c}\text { Trial } \\
\text { Number }\end{array}$ & Status & Phases \\
\hline CAR-T for Children With Relapsed and Refractory Acute Lymphoblastic Leukemia & NCT04626765 & Recruiting & $\begin{array}{l}\text { Early } \\
\text { Phase I }\end{array}$ \\
\hline Inotuzumab Ozogamicin Post-Transplant For Acute Lymphocytic Leukemia & NCT03I0449I & Recruiting & $\begin{array}{l}\text { Phase II } \\
\text { Phase } 2\end{array}$ \\
\hline A Clinical Research of CD22-Targeted CAR-T in B Cell Malignancies & NCT03999697 & Recruiting & Phase I \\
\hline CDI9/22 CAR T Cells (AUTO3) for the Treatment of Diffuse Large B Cell Lymphoma & NCT032878I7 & Recruiting & $\begin{array}{l}\text { Phase II } \\
\text { Phase } 2\end{array}$ \\
\hline Dual Target CAR-T Cells in B-cell Acute Lymphoblastic Leukemia & NCT0472390I & Recruiting & $\begin{array}{l}\text { Phase II } \\
\text { Phase } 2\end{array}$ \\
\hline $\begin{array}{l}\text { Anti-CD22 Chimeric Receptor T Cells in Pediatric and Young Adults With Recurrent or } \\
\text { Refractory CD22-expressing B Cell Malignancies }\end{array}$ & NCT023I56I2 & Recruiting & Phase I \\
\hline $\begin{array}{l}\text { Phase I Study of Anti-CD22 Chimeric Receptor T Cells in Patients With Relapsed/Refractory } \\
\text { Hairy Cell Leukemia and Variant }\end{array}$ & NCT048I5356 & $\begin{array}{l}\text { Not yet } \\
\text { recruiting }\end{array}$ & Phase I \\
\hline CMC-544 and Allogeneic Transplantation for CD22 Positive-Lymphoid Malignancies & NCT0I6649I0 & $\begin{array}{l}\text { Active, not } \\
\text { recruiting }\end{array}$ & $\begin{array}{l}\text { Phase II } \\
\text { Phase } 2\end{array}$ \\
\hline A Phase I Study of CD22-CAR TCell Immunotherapy for CD22+ Leukemia and Lymphoma & NCT03244306 & $\begin{array}{l}\text { Active, not } \\
\text { recruiting }\end{array}$ & Phase I \\
\hline A Treatment Study Protocol for Participants I-45 Years With Acute Lymphoblastic Leukaemia & NCT04307576 & Recruiting & Phase 3 \\
\hline $\begin{array}{l}\text { Safety and Efficacy of CDI9 and CD22 Targeted CAR-T Therapy for Relapsed/Refractory B Cell } \\
\text { Leukemia and Lymphoma }\end{array}$ & NCT04648475 & Recruiting & $\begin{array}{l}\text { Phase II } \\
\text { Phase } 2\end{array}$ \\
\hline $\begin{array}{l}\text { CDI9 and CD22 Targeted CAR-T Cell Therapy for Relapsed/Refractory B Cell Leukemia and } \\
\text { Lymphoma }\end{array}$ & NCT04649983 & Recruiting & $\begin{array}{l}\text { Phase II } \\
\text { Phase } 2\end{array}$ \\
\hline Anti-CD22 CAR-T Cell Therapy Targeting B Cell Malignancies & NCT03262298 & Recruiting & $\begin{array}{l}\text { Phase II } \\
\text { Phase } 2\end{array}$ \\
\hline A Clinical Research of CD22-Targeted CAR-T in B Cell Malignancies & NCT02935I53 & Recruiting & $\begin{array}{l}\text { Phase II } \\
\text { Phase } 2\end{array}$ \\
\hline Immunotherapy With CD22 CAR T-cells for B-Cell Lymphoma, ALL and CLL & NCT04I63575 & $\begin{array}{l}\text { Not yet } \\
\text { recruiting }\end{array}$ & $\begin{array}{l}\text { Phase II } \\
\text { Phase } 2\end{array}$ \\
\hline $\begin{array}{l}\text { A Feasibility and Safety Study of Dual Specificity CDI9 and CD22 CAR-T Cell Immunotherapy } \\
\text { for CD19+CD22+ Leukemia }\end{array}$ & NCT0333069। & Recruiting & Phase I \\
\hline $\begin{array}{l}\text { A Pediatric and Young Adult Trial of Genetically Modified T Cells Directed Against CD22 for } \\
\text { Relapsed/Refractory Leukemia or Lymphoma }\end{array}$ & NCT0457II38 & Recruiting & $\begin{array}{l}\text { Phase II } \\
\text { Phase } 2\end{array}$ \\
\hline Leukapheresis for CAR or Adoptive Cell Therapy Manufacturing & NCT03226704 & Recruiting & \\
\hline $\begin{array}{l}\text { A Study Of Two Inotuzumab Ozogamicin Doses in Relapsed/ Refractory Acute Lymphoblastic } \\
\text { Leukemia Transplant Eligible Patients }\end{array}$ & NCT03677596 & Recruiting & Phase 4 \\
\hline $\begin{array}{l}\text { Targeting CDI9 and CD22 CAR-T Cells Immunotherapy in Patients With Relapsed or } \\
\text { Refractory B Cell Lymphoma }\end{array}$ & NCT047I52I7 & Recruiting & $\begin{array}{l}\text { Phase II } \\
\text { Phase } 2\end{array}$ \\
\hline
\end{tabular}

(Continued) 
Table I (Continued).

\begin{tabular}{|c|c|c|c|}
\hline Title & $\begin{array}{l}\text { Trial } \\
\text { Number }\end{array}$ & Status & Phases \\
\hline $\begin{array}{l}\text { A Single-center Clinical Study to Evaluate the Safety, Tolerability, and Efficacy of LCAR-LIOD Cell } \\
\text { Formulations Targeting CDI9 and CD22 in Patients With CDI9- and/or CD22-Positive } \\
\text { Relapsed/Refractory B-cell Lymphoma }\end{array}$ & NCT03593109 & Recruiting & Phase I \\
\hline $\begin{array}{l}\text { A Study of JNJ-75348780 in Participants With Non-Hodgkin Lymphoma (NHL) and Chronic } \\
\text { Lymphocytic Leukemia (CLL) }\end{array}$ & NCT04540796 & Recruiting & Phase I \\
\hline Study of TRPH-222 in Patients With Relapsed and/or Refractory B-Cell Lymphoma & NCT03682796 & Recruiting & Phase I \\
\hline Anti-CD19/CD22 Bispecific CAR-T Cell Therapy for MRD Positive ALL & NCT03919526 & Recruiting & Phase I \\
\hline $\begin{array}{l}\text { Targeting CDI9 and BCMA CAR-T Cells Immunotherapy in Patients With Relapsed or } \\
\text { Refractory Multiple Myeloma }\end{array}$ & NCT047I 4827 & Recruiting & $\begin{array}{l}\text { Phase II } \\
\text { Phase } 2\end{array}$ \\
\hline $\begin{array}{l}\text { Inotuzumab Ozogamicin in Treating Younger Patients With B-Lymphoblastic Lymphoma or } \\
\text { Relapsed or Refractory CD22 Positive B Acute Lymphoblastic Leukemia }\end{array}$ & NCT0298I628 & Recruiting & Phase 2 \\
\hline $\begin{array}{l}\text { Inotuzumab Ozogamicin and Chemotherapy in Treating Patients With Recurrent or Refractory } \\
\text { B-cell Acute Lymphoblastic Leukemia }\end{array}$ & NCT0399I884 & Recruiting & Phase I \\
\hline CD19/CD22-Dual-STAR-T for Patients With B Cell Acute Leukemia(B-ALL) & NCT04508842 & $\begin{array}{l}\text { Not yet } \\
\text { recruiting }\end{array}$ & Phase I \\
\hline Study of Anti-CD22 CAR NK Cells in Relapsed and Refractory B Cell Lymphoma & NCT03692767 & $\begin{array}{l}\text { Not yet } \\
\text { recruiting }\end{array}$ & $\begin{array}{c}\text { Early } \\
\text { Phase I }\end{array}$ \\
\hline CAR-T Cells in Treating Patients With Relapsed or Refractory NHL & NCT04626739 & Recruiting & $\begin{array}{l}\text { Early } \\
\text { Phase I }\end{array}$ \\
\hline Anti-CDI9 Allo-CAR-T Cells for Relapsed B Cell Malignancies After HSCT & NCT045I655I & Recruiting & Phase I \\
\hline $\begin{array}{l}\text { A Study of CD20/CD22 Targeted CAR T-cell Therapy for Relapsed or Refractory Lymphoid } \\
\text { Malignancies }\end{array}$ & NCT04283006 & Recruiting & $\begin{array}{c}\text { Early } \\
\text { Phase I }\end{array}$ \\
\hline $\begin{array}{l}\text { Clinical Study of Targeting CDI9 and CD22 Chimeric Antigen Receptor T Lymphocytes in the } \\
\text { Treatment of Recurrent or Refractory B Cell Non-Hodgkin Lymphoma }\end{array}$ & NCT04626908 & $\begin{array}{l}\text { Not yet } \\
\text { recruiting }\end{array}$ & $\begin{array}{l}\text { Phase II } \\
\text { Phase } 2\end{array}$ \\
\hline $\begin{array}{l}\text { A Clinical Study of CAR-T Cells Treatment for Children With CDI9+/CD22+R/R ALL and } \\
\text { Lymphoma }\end{array}$ & NCT04204I6I & Recruiting & Phase I \\
\hline CAR-T for R/R B-NHL & NCT03196830 & Recruiting & Phase 2 \\
\hline $\begin{array}{l}\text { CD19-CD22 Chimeric Antigen Receptor T (CAR-T) Cell for Treatment of B Cell Acute } \\
\text { Lymphoblastic Leukemia (B-ALL) }\end{array}$ & NCT04034446 & $\begin{array}{l}\text { Active, not } \\
\text { recruiting }\end{array}$ & $\begin{array}{l}\text { Early } \\
\text { Phase I }\end{array}$ \\
\hline $\begin{array}{l}\text { An Early Access Programme for Moxetumomab Pasudotox in Relapsed/Refractory Hairy Cell } \\
\text { Leukemia }\end{array}$ & NCT03501615 & $\begin{array}{l}\text { Approved for } \\
\text { marketing }\end{array}$ & \\
\hline
\end{tabular}

Notes: Data from clinicaltrials.gov (Accessed May II, 202I).

T-cells to target CD19-positive B-ALL blasts. ${ }^{50}$ Conclusions

NCT04540796 is an ongoing phase I trial with JNJ- CD22 is an attractive target for B-cell malignancies given its 75348780, a bispecific antibody targeting CD3 and CD22 strong expression in the majority of B-lymphoid cells. in patients with relapsed refractory NHL, including CLL. Mechanisms for CD22 targeting include monoclonal antiboPreliminary results have not been published at this time. dies (epratuzumab), antibody-drug conjugates (inotuzumab 
ozogamicin, moxetumomab pasudotox), radioimmunoconjugates (epratuzumab tetraxetan), CAR-T cells, and bispecific antibodies. In current practice, the antibody-drug conjugate inotuzumab ozogamicin appears to be the most frequently used anti-CD22 therapy and is FDA approved for use in relapsed/refractory B-ALL. Anti-CD22 CAR-T therapies are currently in clinical trials, and early results appear promising. Future directions for CD22 targeted therapies include more prospective trials with CD22 CARs, bispecific antibodies, and combining CARs with anti-CD-19 CARS, either sequentially or in bispecific CARs. A list of selected currently ongoing clinical trials using anti-CD22 immunotherapeutic agents is included in Table 1.

\section{Consent for Publication}

All authors consent to publication.

\section{Author Contributions}

All authors made a significant contribution to the work reported, whether that is in the conception, study design, execution, acquisition of data, analysis and interpretation, or in all these areas; took part in drafting, revising or critically reviewing the article; gave final approval of the version to be published; have agreed on the journal to which the article has been submitted; and agreed to be accountable for all aspects of the work.

\section{Funding}

No funding was utilized for this systematic review.

\section{Disclosure}

The authors reported no conflicts of interest for this work.

\section{References}

1. Teras LR, DeSantis CE, Cerhan JR, Morton LM, Jemal A, Flowers CR. US lymphoid malignancy statistics by World Health Organization subtypes. CA Cancer J Clin. 2016;66(6):443-459. doi: $10.3322 /$ caac. 21357

2. Morrison VA, Hong F, Habermann TM, et al. R-CHOP Versus (vs) CHOP Followed by Maintenance Rituximab (MR) Vs Observation In Older Diffuse Large B-Cell Lymphoma (DLBCL) Patients (pts): long-Term Follow-up of Intergroup E4494/C9793. Blood. 2010;116:589. doi:10.1182/blood.V116.21.589.589

3. Marcus R, Davies A, Ando K, et al. Obinutuzumab for the First-Line Treatment of Follicular Lymphoma. N Engl J Med. 2017;377 (14):1331-1344. doi:10.1056/NEJMoa1614598

4. Goldenberg DM. Epratuzumab in the therapy of oncological and immunological diseases. Expert Rev Anticancer Ther. 2006;6 (10):1341-1353. doi:10.1586/14737140.6.10.1341

5. Doody GM, Justement LB, Delibrias CC, et al. A role in B cell activation for CD22 and the protein tyrosine phosphatase SHP. Science. 1995;269(5221):242-244. doi:10.1126/science.7618087
6. Tuscano JM, Riva A, Toscano SN, Tedder TF, Kehrl JH. CD22 cross-linking generates B-cell antigen receptor-independent signals that activate the JNK/SAPK signaling cascade. Blood. 1999;94 (4):1382-1392. doi:10.1182/blood.V94.4.1382

7. Raetz EA, Cairo MS, Borowitz MJ, et al. Chemoimmunotherapy reinduction with epratuzumab in children with acute lymphoblastic leukemia in marrow relapse: a Children's Oncology Group Pilot Study. J Clin Oncol. 2008;26(22):3756-3762. doi:10.1200/ jco.2007.15.3528

8. Raetz EA, Cairo MS, Borowitz MJ, et al. Re-induction chemoimmunotherapy with epratuzumab in relapsed acute lymphoblastic leukemia (ALL): phase II results from Children's Oncology Group (COG) study ADVL04P2. Pediatr Blood Cancer. 2015;62(7):1171-1175. doi: $10.1002 / p b c .25454$

9. Raetz EA, Borowitz MJ, Devidas M, et al. Reinduction platform for children with first marrow relapse of acute lymphoblastic Leukemia: a Children's Oncology Group Study[corrected]. J Clin Oncol. 2008;26(24):3971-3978. doi:10.1200/jco.2008.16.1414

10. Advani AS, McDonough S, Coutre S, et al. SWOG S0910: a Phase 2 trial of clofarabine/cytarabine/epratuzumab for relapsed/refractory acute lymphocytic leukaemia. $B r \quad J \quad$ Haematol. 2014;165 (4):504-509. doi:10.1111/bjh. 12778

11. Advani AS, Gundacker HM, Sala-Torra O, et al. Southwest Oncology Group Study S0530: a phase 2 trial of clofarabine and cytarabine for relapsed or refractory acute lymphocytic leukaemia. $\mathrm{Br} \mathrm{J} \mathrm{Haematol.}$ 2010;151(5):430-434. doi:10.1111/j.1365-2141.2010.08387.x

12. Chevallier P, Huguet F, Raffoux E, et al. Vincristine, dexamethasone and epratuzumab for older relapsed/refractory CD22+ B-acute lymphoblastic leukemia patients: a phase II study. Haematologica. 2015;100(4):e128-31. doi:10.3324/haematol.2014.120220

13. Leonard JP, Coleman M, Ketas J, et al. Combination antibody therapy with epratuzumab and rituximab in relapsed or refractory nonHodgkin's lymphoma. J Clin Oncol. 2005;23(22):5044-5051. doi:10.1200/jco.2005.13.821

14. Leonard JP, Coleman M, Ketas JC, et al. Phase I/II trial of epratuzumab (humanized anti-CD22 antibody) in indolent non-Hodgkin's lymphoma. J Clin Oncol. 2003;21(16):3051-3059. doi:10.1200/ jco.2003.01.082

15. Leonard JP, Coleman M, Ketas JC, et al. Epratuzumab, a humanized anti-CD22 antibody, in aggressive non-Hodgkin's lymphoma: phase I/II clinical trial results. Clin Cancer Res. 2004;10(16):5327-5334. doi:10.1158/1078-0432.Ccr-04-0294

16. Strauss SJ, Morschhauser F, Rech J, et al. Multicenter phase II trial of immunotherapy with the humanized anti-CD22 antibody, epratuzumab, in combination with rituximab, in refractory or recurrent nonHodgkin's lymphoma. J Clin Oncol. 2006;24(24):3880-3886. doi:10.1200/jco.2006.05.6291

17. Leonard JP, Schuster SJ, Emmanouilides C, et al. Durable complete responses from therapy with combined epratuzumab and rituximab: final results from an international multicenter, phase 2 study in recurrent, indolent, non-Hodgkin lymphoma. Cancer. 2008;113 (10):2714-2723. doi:10.1002/cncr.23890

18. Micallef IN, Kahl BS, Maurer MJ, et al. A pilot study of epratuzumab and rituximab in combination with cyclophosphamide, doxorubicin, vincristine, and prednisone chemotherapy in patients with previously untreated, diffuse large B-cell lymphoma. Cancer. 2006;107 (12):2826-2832. doi:10.1002/cncr.22342

19. Micallef IN, Maurer MJ, Wiseman GA, et al. Epratuzumab with rituximab, cyclophosphamide, doxorubicin, vincristine, and prednisone chemotherapy in patients with previously untreated diffuse large B-cell lymphoma. Blood. 2011;118(15):4053-4061. doi:10.1182/ blood-2011-02-336990

20. Shor B, Gerber HP, Sapra P. Preclinical and clinical development of inotuzumab-ozogamicin in hematological malignancies. Mol Immunol. 2015;67(2Pt A):107-116. doi:10.1016/j.molimm.2014. 09.014 
21. Kantarjian HM, DeAngelo DJ, Stelljes M, et al. Inotuzumab ozogamicin versus standard of care in relapsed or refractory acute lymphoblastic leukemia: final report and long-term survival follow-up from the randomized, Phase 3 INO-VATE study. Cancer. 2019;125 (14):2474-2487. doi:10.1002/cncr.32116

22. Kantarjian HM, DeAngelo DJ, Stelljes M, et al. Inotuzumab Ozogamicin versus Standard Therapy for Acute Lymphoblastic Leukemia. $N$ Engl J Med. 2016;375(8):740-753. doi:10.1056/ NEJMoa1509277

23. Jabbour E, Sasaki K, Ravandi F, et al. Chemoimmunotherapy with inotuzumab ozogamicin combined with mini-hyper-CVD, with or without blinatumomab, is highly effective in patients with Philadelphia chromosome-negative acute lymphoblastic leukemia in first salvage. Cancer. 2018;124(20):4044-4055. doi:10.1002/cncr.31720

24. Kantarjian H, Ravandi F, Short NJ, et al. Inotuzumab ozogamicin in combination with low-intensity chemotherapy for older patients with Philadelphia chromosome-negative acute lymphoblastic leukaemia: a single-arm, phase 2 study. Lancet Oncol. 2018;19(2):240-248. doi:10.1016/s1470-2045(18)30011-1

25. Martell MP, Atenafu EG, Minden MD, et al. Treatment of elderly patients with acute lymphoblastic leukaemia using a paediatric-based protocol. $\mathrm{Br} J$ Haematol. 2013;163(4):458-464. doi:10.1111/ bjh. 12561

26. Advani A, Coiffier B, Czuczman MS, et al. Safety, pharmacokinetics, and preliminary clinical activity of inotuzumab ozogamicin, a novel immunoconjugate for the treatment of B-cell non-Hodgkin's lymphoma: results of a phase I study. $J$ Clin Oncol. 2010;28 (12):2085-2093. doi:10.1200/JCO.2009.25.1900

27. Fayad L, Offner F, Smith MR, et al. Safety and clinical activity of a combination therapy comprising two antibody-based targeting agents for the treatment of non-Hodgkin lymphoma: results of a phase I/II study evaluating the immunoconjugate inotuzumab ozogamicin with rituximab. $J$ Clin Oncol. 2013;31(5):573-583. doi:10.1200/JCO.2012.42.7211

28. Ogura M, Tobinai K, Hatake K, et al. Phase I study of inotuzumab ozogamicin (CMC-544) in Japanese patients with follicular lymphoma pretreated with rituximab-based therapy. Cancer Sci. 2010;101(8):1840-1845. doi:10.1111/j.1349-7006.2010.01601.x

29. Dang NH, Ogura M, Castaigne S, et al. Randomized, phase 3 trial of inotuzumab ozogamicin plus rituximab versus chemotherapy plus rituximab for relapsed/refractory aggressive B-cell non-Hodgkin lymphoma. Br J Haematol. 2018;182(4):583-586. doi:10.1111/ bjh. 14820

30. Kreitman RJ, Pastan I. Antibody fusion proteins: anti-CD22 recombinant immunotoxin moxetumomab pasudotox. Clin Cancer Res. 2011;17(20):6398-6405. doi:10.1158/1078-0432.Ccr-11-0487

31. Kreitman RJ, Dearden C, Zinzani PL, et al. Moxetumomab pasudotox in relapsed/refractory hairy cell leukemia. Leukemia. 2018;32 (8):1768-1777. doi:10.1038/s41375-018-0210-1

32. Shah NN, Bhojwani D, August K, et al. Results from an international phase 2 study of the anti-CD22 immunotoxin moxetumomab pasudotox in relapsed or refractory childhood B-lineage acute lymphoblastic leukemia. Pediatr Blood Cancer. 2020;67(5):e28112. doi: $10.1002 /$ pbc. 28112

33. Short NJ, Kantarjian H, Jabbour E, et al. A phase I study of moxetumomab pasudotox in adults with relapsed or refractory B-cell acute lymphoblastic leukaemia. $B r \quad J$ Haematol. 2018;182 (3):442-444. doi:10.1111/bjh.14806

34. Kreitman RJ, Squires DR, Stetler-Stevenson M, et al. Phase I trial of recombinant immunotoxin RFB4(dsFv)-PE38 (BL22) in patients with B-cell malignancies. J Clin Oncol. 2005;23(27):6719-6729. doi:10.1200/JCO.2005.11.437

35. Kreitman RJ, Stetler-Stevenson M, Margulies I, et al. Phase II trial of recombinant immunotoxin RFB4(dsFv)-PE38 (BL22) in patients with hairy cell leukemia. J Clin Oncol. 2009;27(18):2983-2990. doi:10.1200/JCO.2008.20.2630
36. Kreitman RJ, Wilson WH, Bergeron K, et al. Efficacy of the anti-CD22 recombinant immunotoxin BL22 in chemotherapy-resistant hairy-cell leukemia. $N$ Engl $J$ Med. 2001;345(4):241-247. doi:10.1056/NEJM200107263450402

37. Sausville EA, Headlee D, Stetler-Stevenson M, et al. Continuous infusion of the anti-CD22 immunotoxin IgG-RFB4-SMPT-dgA in patients with B-cell lymphoma: a phase I study. Blood. 1995;85(12):3457-3465. doi:10.1182/blood.V85.12.3457.bloodjournal85123457

38. Bachanova V, Frankel AE, Cao Q, et al. Phase I study of a bispecific ligand-directed toxin targeting CD22 and CD19 (DT2219) for refractory B-cell malignancies. Clin Cancer Res. 2015;21(6):1267-1272. doi:10.1158/1078-0432.Ccr-14-2877

39. Chevallier P, Eugene T, Robillard N, et al. (90)Y-labelled anti-CD22 epratuzumab tetraxetan in adults with refractory or relapsed CD22positive B-cell acute lymphoblastic leukaemia: a phase 1 dose-escalation study. Lancet Haematol. 2015;2(3):e108-117. doi:10.1016/ s2352-3026(15)00020-4

40. Morschhauser F, Kraeber-Bodéré F, Wegener WA, et al. High rates of durable responses with anti-CD22 fractionated radioimmunotherapy: results of a multicenter, phase I/II study in non-Hodgkin's lymphoma. J Clin Oncol. 2010;28(23):3709-3716. doi:10.1200/jco.2009.27.7863

41. Witzig TE, Tomblyn MB, Misleh JG, et al. Anti-CD22 90Y-epratuzumab tetraxetan combined with anti-CD20 veltuzumab: a phase I study in patients with relapsed/refractory, aggressive non-Hodgkin lymphoma. Haematologica. 2014;99(11):1738-1745. doi:10.3324/haematol.2014.112110

42. Kraeber-Bodere F, Pallardy A, Maisonneuve H, et al. Consolidation anti-CD22 fractionated radioimmunotherapy with (90) Y-epratuzumabtetraxetan following R-CHOP in elderly patients with diffuse large B-cell lymphoma: a prospective, single group, phase 2 trial. Lancet Haematol. 2017;4(1):e35-e45. doi:10.1016/ s2352-3026(16)30168-5

43. Zinzani PL, Tani M, Fanti S, et al. A phase II trial of CHOP chemotherapy followed by yttrium 90 ibritumomab tiuxetan (Zevalin) for previously untreated elderly diffuse large B-cell lymphoma patients. Ann Oncol. 2008;19(4):769-773. doi:10.1093/ annonc/mdm560

44. Linden O, Bates AT, Cunningham D, et al. Thorium-227-Labeled Anti-CD22 Antibody (BAY 1862864) in Relapsed/Refractory CD22-Positive Non-Hodgkin Lymphoma: a First-in-Human, Phase I Study. Cancer Biother Radiopharm. 2021. doi:10.1089/ cbr.2020.4653

45. Fry TJ, Shah NN, Orentas RJ, et al. CD22-targeted CAR T cells induce remission in B-ALL that is naive or resistant to CD19-targeted CAR immunotherapy. Nat Med. 2018;24(1):20-28. doi:10.1038/ nm. 4441

46. Shah NN, Highfill SL, Shalabi H, et al. CD4/CD8 T-Cell Selection Affects Chimeric Antigen Receptor (CAR) T-Cell Potency and Toxicity: updated Results From a Phase I Anti-CD22 CAR T-Cell Trial. J Clin Oncol. 2020;38(17):1938-1950. doi:10.1200/ jco.19.03279

47. Dai $\mathrm{H}, \mathrm{Wu} \mathrm{Z}$, Jia $\mathrm{H}$, et al. Bispecific CAR-T cells targeting both CD19 and CD22 for therapy of adults with relapsed or refractory B cell acute lymphoblastic leukemia. J Hematol Oncol. 2020;13 (1):30. doi:10.1186/s13045-020-00856-8

48. Titov A, Zmievskaya E, Ganeeva I, et al. Adoptive Immunotherapy beyond CAR T-Cells. Cancers. 2021;13(4):743. doi:10.3390/ cancers13040743

49. Schneider D, Xiong Y, Wu D, et al. Trispecific CD19-CD20-CD22targeting duoCAR-T cells eliminate antigen-heterogeneous B cell tumors in preclinical models. Sci Transl Med. 2021;13(586): eabc6401. doi:10.1126/scitranslmed.abc6401

50. Kantarjian H, Stein A, Gokbuget N, et al. Blinatumomab versus Chemotherapy for Advanced Acute Lymphoblastic Leukemia. $N$ Engl J Med. 2017;376(9):836-847. doi:10.1056/ NEJMoa1609783 


\section{Publish your work in this journal}

ImmunoTargets and Therapy is an international, peer-reviewed open access journal focusing on the immunological basis of diseases, potential targets for immune based therapy and treatment protocols employed to improve patient management. Basic immunology and physiology of the immune system in health, and disease will be also covered. In addition, the journal will focus on the impact of management

Submit your manuscript here: http://www.dovepress.com/immunotargets-and-therapy-journal programs and new therapeutic agents and protocols on patient perspectives such as quality of life, adherence and satisfaction. The manuscript management system is completely online and includes a very quick and fair peer-review system, which is all easy to use. Visit http://www.dovepress.com/testimonials.php to read real quotes from published authors. 